
\title{
藤田克昌 ${ }^{1,2}$, 袖岡幹子 2,3 \\ ${ }^{1}$ 大阪大学院工学研究科精密科学・応用物理学専攻 \\ ${ }^{2}$ ERATO $\cdot$ JST \\ ${ }^{3}$ 理化学研究所基幹研究所
}

微小タグとラマン顕微鏡による小分子イメージング

\section{1. 見えているのは分子の特性 ? ラベルの特性 ?}

蛍光ラベルは，観察対象となる生体分子や外部から 投入した化合物の所在を明らかにする。しかし，蛍光 ラベルは万能ではなく，ラベリングすることによる化 学的, 生物的な特性の変化が現れる場合がある. 特に 小さな構造の分子の場合, その特性変化は顕著であ る。たとえば，抗がん剂として知られるフルオロウラ シル（5-FU）の分子量 130 に対して，代表的な蛍光 団の Rhodamine 6G は分子量 479である. これでは, 化合物の特性を観察しているのか，ラベルの特性を観 察しているのかわからない.

最近，われわれは，観察対象が小さな分子であって も，その機能を阻害しない微小なタグの開発を行って いる. 蛍光観察以外にもさまざまな光学的な顕微観察 法があり，その中でもラマン散乱顕微鏡は，試料内の 分子の振動を検出することで分子の所在を明らかにす る.われわれはユニークな分子振動を示す構造を微小 なタグとして利用し，ラマン散乱顕微鏡により検出す ることを試みた.

\section{2. | ラマン散乱とラマンタグ}

ラマン散乱とは, 光を分子に照射した際に生じる, 光の波長変化の効果であり，その波長の変化量は試料 中の分子の振動数に依存する ${ }^{1)}$. その振動数は分子の 構造に固有であるため, ラマン散乱のスペクトルを分 光計測すれば，どのような構造の分子が試料中に存在 するか把握できる.

波長 $532 \mathrm{~nm}$ の光を細胞に照射し，554-633 nm の散 乱光（波数 ${ }^{*} 750-3000 \mathrm{~cm}^{-1}$ のラマンシフトに相当）の 強度を測定して得たラマン散乱スペクトルを図 1aに 示す. 細胞内分子のラマン散乱は1800-2700 $\mathrm{cm}^{-1}$ の波 数領域に強いラマン散乱をもたない（Silent Region と よばれる）ため, この領域にラマン散乱ピークを示す
官能基を分子に導入すれば，ラマン散乱を用いて，そ の分子を細胞内で特異的に検出できると考えられる.

われわれは，この領域にラマン散乱ピークを示す分 子構造として, 炭素-炭素 3 重結合を有するアルキニル 基に着目した ${ }^{2)}$. アルキニル基は2100- $2300 \mathrm{~cm}^{-1}$ に炭 素-炭素 3 重結合に由来するラマン散乱ピークをもつ. 生体内には3 重結合を有する分子はほとんど存在しな いため, アルキニル基由来のラマン散乱光は, 他の分 子からの散乱光と分離して検出される. もっとも小さ なアルキニル基であるエチニル基は，炭素 2 個と水素 1 個のみで構成されることから, 従来の蛍光ラベルよ りも格段に小さいタグとして使用できると考えた.

図 $1 \mathrm{~b}$ にチニル基を有する化合物として EdU (5-ethynyl-2'-deoxyuridine) の構造を示す. EdU と細胞 のスペクトルを比較（図 1a）すると， $2122 \mathrm{~cm}^{-1}$ に炭 素 3 重結合の伸縮振動（炭素原子間の距離が伸び縮み する振動）に由来する強いラマン散乱ピークが，上で 述べた“Silent Region”に現れていることがわかる.

\section{3.|微小タグを利用した小分子イメージング}

われわれは，EdUを HeLa 細胞内に取り込ませそそ の細胞内分布をラマン散乱顕微鏡 ${ }^{3)} に よ り$ 観察した. $\mathrm{EdU}$ はデオキシウリジン (dU) にエチニル基を導入し た構造をもって拈り，DNAの原料であるデオキシチ ミジン (dT) と間違えて細胞に取り込まれ, 細胞の DNA 合成にあわせて，核内に集積すると予想される.

図 2 に EdU と共に 12 時間培養した HeLa 細胞から 得られたラマン散乱スペクトルを示す. 細胞由来のラマ ン散乱光に加え, 核ではエチニル基に由来するラマン散 乱ピークが $2123 \mathrm{~cm}^{-1}$ の波数に打いて $15 \mathrm{~cm}^{-1}$ 程度の広 がりをもって確認できる（ラマン散乱ピークは分子の 周辺環境により若干シフトまた広がることがあり，こ の測定では，図1の結果よりわずかにずれた位置に エチニル基由来のラマン散乱が現れたと考えられる). 
このエチニル基によるラマン散乱光の分布を図 3 に 示す. エチニル基の他, シトクローム C, タンパク質, 脂質分子内の結合に帰属できるラマン散乱光の分布も 示した. これらの図より,エチニル基のラマン散乱ピー クの細胞核内への局在を確認できる.さらに, EdUと の培養時間を変化させながら同様の観察を行った結
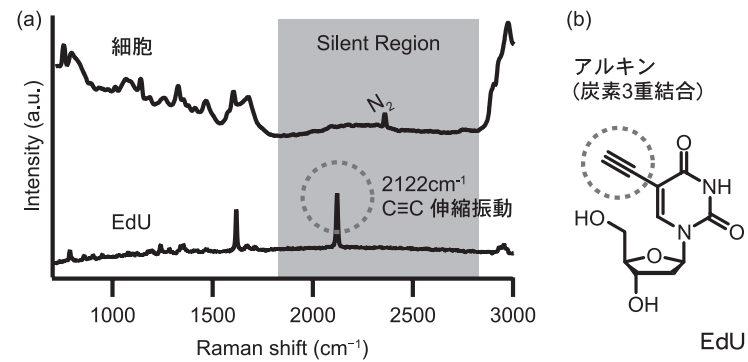

図 1

（a）HeLa 細胞，および EdU (固体) のラマン散乱スペクトル. EdU の分子構造.

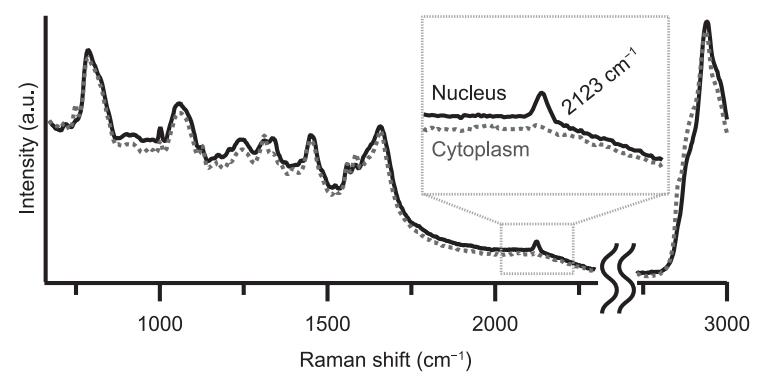

闵 2

EdU を導入した HeLa 細胞のラマン散乱スペクトル
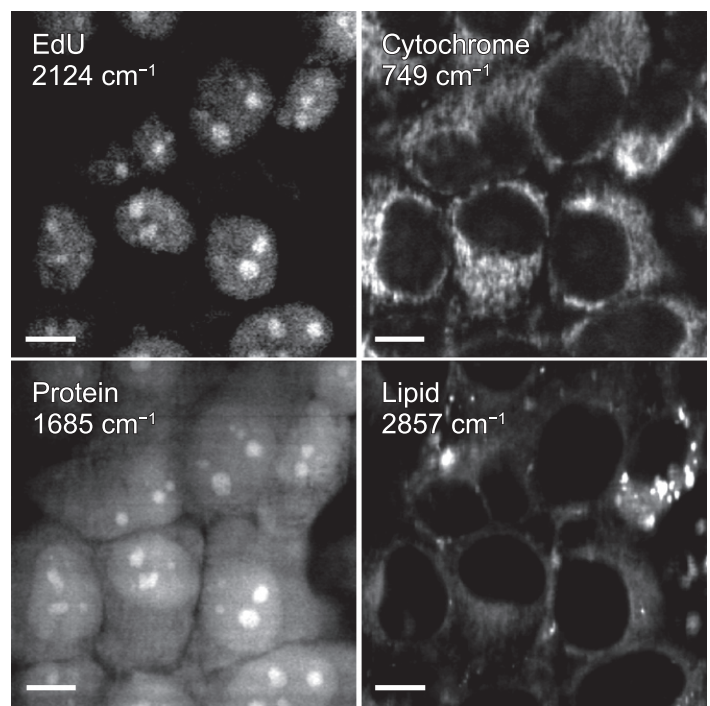

図 3

EdUを導入した HeLa 細胞のラマン像. それぞれ，2124，749， $1685,2857 \mathrm{~cm}^{-1}$ のラマン散乱の強度分布を示す. 励起波長 $532 \mathrm{~nm}$ ，スケールバー $10 \mu \mathrm{m}$. 撮像時間約 40 分. 画像ピクセル 数, および空間分解能は $190 \times 400$, および約 $0.3 \mu \mathrm{m}$ (回折限界).

果, 時間と共に EdUの核内への取り込みが進行し，約 21 時間後, 視野内のほぼすべての細胞において EdUの 取り込みを確認できた。この $\mathrm{EdU} の$ 核内蓄積の時間 応答は，細胞の増殖周期とほぼ同じであり，タグの導 入による $\mathrm{dU}$ の特性変化はほとんどないと考えられる.

\section{4.| ラマンタグの可能生}

ラマンタグを用いれば従来の蛍光観察法では追跡で きなかった小分子の細胞内の挙動を追跡できる。しか し，本手法の最大の弱点は，ラマン散乱の散乱効率が 低く，長い測定時間を要すること，低濃度の分子の検 出が難しいこと（実験結果より，EdUの場合，数 $100 \mu \mathrm{M}$ の濃度が必要と推測）にある。しかし，今後， より高感度に分子振動を検出できるとされるコヒーレ ントラマン散乱 ${ }^{4)}$,5) の利用や，より高い散乱効率をも つラマンタグの開発により，よりダイナミックな小分 子の細胞内動態の観察が実現できると考えている.

“Silent Region”の利用は, アルキニル基の導入以外で も可能である. たとえば, 水素分子を重水素で置換すれ ば, CD 結合の伸縮振動を“Silent Region”に出現させら れる. 重水素を含むアミノ酸を細胞内に取り込ませ, そのタンパク質代謝を可視化した報告がある ${ }^{6}$. ラマ ン散乱による分子振動検出も以前と比べ技術的に容易 になっており，それを利用した新しい細胞分析法・イ メージング法が今後も登場すると期待している.

文 献

1）溑口宏夫, 平川暁子（1988）ラマン分光法, 学会出版センター.

2) Yamakoshi, H. et al. (2011) J. Am. Chem. Soc. 133, 6102-6105.

3) Hamada, K. et al. (2008) J. Biomed. Opt. 13, 044027.

4) Cheng, J. X., Xie, X. S. (2004) J. Phys. Chem. B 108, 827-840.

5) Freudiger, C. W. et al. (2008) Science 322, 1857-1861.

6) Manen, H. J. et al. (2008) Anal. Chem. 80, 9576-9582.

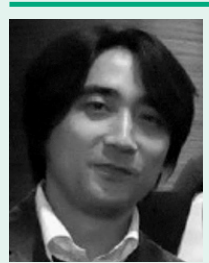

藤田克昌（ふじた かつまさ） 大阪大学大学院工学研究科准教授 2000 年大阪大学大学院工学研究科博士後期課程 修了. 博士 (工学). 日本学術振興会研究員, 大 阪大学学助手を経て, 07 年より現職. 08 年から ERATO グループリーダーを兼務. 研究内容: 生体 観察のための光学顕微鏡の開発.

藤田克昌 連絡先: ₹ 565-0871 大阪府吹田市山田丘 2-1 E-mail: fujita@ap.eng.osaka-u.ac.jp

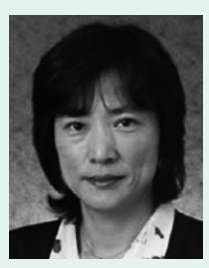

袖岡幹子
袖岡幹子 (そでおか みきこ)

理化学研究所主任研究員

1983 年千葉大学大学院薬学研究科博士前期課程 修了 (89 年薬学博士). 相模中央化学研究所, 北 海道大学, ハーバード大学, 東京大学, 東北大学 を経て, 06 年から現職. 08 年から ERATO 研究 総括を兼務.

研究内容:生命現象メカニズムの解明に役立つ新 しい化合物や方法の開発.

連絡先: ₹ 351-0198 埼玉県和光市広沢 2-1 E-mail: sodeoka@riken.jp 